Artikel Penelitian

\title{
Peningkatan Rasionalitas Penggunaan Antibiotik Pasca Implementasi Kebijakan Penggunaan Antimikroba di RSUD Arifin Achmad Pekanbaru
}

\section{Improvement in Rational Antibiotic Usage after Antimicrobial Stewardship Implementation in Arifin Achmad General Hospital Pekanbaru}

\author{
Dani Rosdiana ${ }^{1}$, Dewi Anggraini ${ }^{2}$, Mukhyarjon Balmas ${ }^{1}$, Dasril Effendi $^{1}$, Anwar Bet $^{1}$ \\ ${ }^{1}$ KJF Ilmu Penyakit Dalam Rumah Sakit Umum Daerah Arifin Achmad Pekanbaru \\ ${ }^{2}$ KJF Mikrobiologi Fakultas Kedokteran Universitas Riau Pekanbaru
}

\begin{abstract}
ABSTRAK
Ancaman global permasalahan resistensi antibiotik membutuhkan strategi pencegahan yang mencakup penggunaan antibiotik secara bijak melalui pengawasan penggunaan antimikroba. Penggunaan antibiotik harus memenuhi beberapa kriteria seperti indikasi, dosis, lama pemakaian, jarak pemberian yang tepat, serta aman dan terjangkau bagi masyarakat, dan juga memenuhi pola mikroba dan kultur. Pada penelitian ini dilakukan analisis rasionalitas penggunaan antibiotik di Bangsal Kenanga RSUD Arifin Achmad Pekanbaru setelah implementasi kebijakan penggunaan antimikroba pada periode Maret hingga Agustus 2016. Terdapat 252 penggunaan antibiotik yang terbagi menjadi dua kelompok, yaitu preimplementasi sebanyak 92 dan pasca-implementasi sebanyak 160 penggunaan antibiotik. Rasionalitas penggunaan antibiotik dinilai dengan metode Gyssens yang dilakukan oleh tim pengkaji. Penggunaan antibiotik rasional meningkat sebanyak $15,1 \%$, penggunaan antibiotik tanpa indikasi menurun sebanyak $10,9 \%$ dan terdapat peningkatan pemeriksaan kultur sebanyak $57,7 \%$. Berdasarkan uji statistik, terdapat peningkatan bermakna rasionalitas penggunaan antibiotik setelah implementasi pedoman penggunaan antibiotik ( $33,7 \%$ vs $48,8 \%, p=0,020)$, dan penurunan penggunaan antibiotik tanpa indikasi $(27,2 \%$ vs $16,3 \%, p=0,038)$. Penerapan kebijakan penggunaan antimikroba efektif meningkatkan rasionalitas penggunaan antibiotik. Program ini dapat diperluas di bangsal lain sehingga rasionalitas penggunaan antibiotik merata di seluruh rumah sakit.
\end{abstract}

Kata Kunci: Gyssens, kebijakan antimikroba, rasionalitas, penggunaan antibiotik

\begin{abstract}
Global threat of antibiotic resistance requires prevention strategies including a wise use of antimicrobials through monitoring of antimicrobial usage. The use of antibiotics should fulfill several criteria, such as indication, dosage, duration of administration, interval of administration, safety and affordable price, and also conform to bacterial and culture patterns. In this study, rationality analysis of antibiotic usage was done in Kenanga Ward Arifin Ahmad General Hospital Pekanbaru after antimicrobial stewardship implementation in the period of March to August 2016 . There were 252 antibiotic usage divided into two groups, i.e. 92 usage during pre-implementation and 160 antibiotic usage during postimplementation. Rationality of antibiotic usage was assessed using Gyssens method. Rational antibiotic use increased by $15.1 \%$, antibiotics use without indication decreased by $10,9 \%$, and there was a $57,7 \%$ increase of culture examination. Based on statistical tests, there was a significant increase in the rationality of antibiotic use after antimicrobial stewardship implementation (33,7\% vs $48,8 \%, p=0,020)$, and decreased use of antibiotics without indication (27,2\% vs $16,3 \%, p=0,038)$. Implementation of antimicrobial stewardship effectively increases rationality of antibiotic usage. This program can be expanded in other wards so that rationality of antibiotic use is evenly distributed throughout the hospital.
\end{abstract}

Keywords: Antimicrobial stewardship, antibiotic usage, Gyssens, rasionality

Korespondensi: Dani Rosdiana. KJF IImu Penyakit Dalam Rumah Sakit Umum Daerah Arifin Achmad Pekanbaru, Jl. Diponogoro No. 1 Pekanbaru, Riau Tel.08122938273Email:dr.danirosdiana@yahoo.com

DOI: http://dx.doi.org/10.21776/ub.jkb.2018.030.01.7 


\section{PENDAHULUAN}

Penyakit infeksi masih merupakan salah satu masalah kesehataan yang mengancam di negara berkembang termasuk Indonesia. Riau sebagai salah satu provinsi dengan cakupan wilayah pesisirnya juga tak luput dari ancaman ini. Tercatat di RSUD Arifin Ahmad Pekanbaru penyakit infeksi masuk dalam 10 besar penyakit. Antibiotik merupakan obat yang paling banyak digunakan (1).

Berbagai studi menemukan bahwa sekitar 40-62\% antibiotik digunakan secara tidak tepat. Intensitas penggunaan antibiotik yang tinggi menimbulkan berbagai permasalahan dan menjadi ancaman global bagi kesehatan terutama resistensi bakteri terhadap antibiotik (2). Kedaruratan kejadian resistensi bakteri terjadi di seluruh dunia dan dikaitkan dengan penggunaan berlebihan dan penggunaan yang tidak tepat obat-obatan ini. Penggunaan antibiotik yang tidak tepat di rumah sakit merupakan salah satu faktor utama yang mendorong kejadian resistensi antibiotik (3-5).

Ancaman resistensi terhadap antibiotik ini mendorong penggunaan antibiotik harus berdasarkan justifikasi yang tepat sehingga menurunkan resistensi antibiotik yang beberapa tahun terakhir menjadi sorotan penting di dunia. Untuk mengoptimalkan penggunaan antibiotik secara bijak perlu disusun berdasarkan pedoman penggunaan antibiotik di sebuah rumah sakit (6). Pedoman ini dibuat berdasarkan pedoman yang dikeluarkan oleh kementerian kesehatan dan disesuaikan dengan laporan pola resistensi di rumah sakit.

Hanberger dkk. melakukan penelitian untuk menilai pengaruh perubahan kebijakan penggunaan antibiotik di rumah sakit di Swedia dengan hasil bahwa aksi untuk memperbaiki penggunaan antibiotik berdasarkan bukti ilmiah dan upaya menurunkan angka resistensi antibiotik harus terus diperkuat (7). Begitu juga dengan penyusunan standar panduan terapi harus terus ditingkatkan baik di tingkat lokal maupun nasional (7). Negara KS di Bali menyimpulkan bahwa implementasi penggunaan antibiotik yang tidak sesuai berpotensi meningkatkan angka resistensi kuman, peningkatan morbiditas dan mortalitas serta lama rawat dan peningkatan biaya rumah sakit (8).

Alur penilaian kualitatif antibiotik bisa dilakukan dengan menggunakan alur dari Gyssens yaitu pemberian antibiotik dikaji oleh tim pengkaji dengan memperhatikan kriteria tepat indikasi, tepat dosis, tepat lama pemberian, tepat interval pemberian obat, aman dan terjangkau oleh penderita serta sesuai dengan pola kuman dan hasil kultur (9). Penggunaan antibiotik dinilai dengan melihat rekam medis pemberian antibotik dan rekam medis pasien dengan mempertimbangkan kesesuaian diagnosis (gejala klinis dan hasil laboratorium), indikasi, regimen dosis, keamanan dan harga (10).

Di negara berkembang peresepan antibiotik mencapai angka 44-97\% pasien yang dirawat di rumah sakit, sering kali pemberiannya tidak perlu dan tidak tepat (11). Beberapa faktor sosial ekonomi dan perilaku diperkirakan berkontribusi terhadap pemakaian antibiotik yang tidak tepat dan sebagai konsekuensinya, akan terjadi peningkatan insidensi resistensi antibiotik (12). Hingga tahun 2015, RSUD Arifin Ahmad Pekanbaru belum memiliki data mengenai rasionalitas penggunaan antibotik. Padahal indikator ini sangat penting dalam pelayanan kesehatan. Selain itu, RSUD Arifin Ahmad juga belum memberlakukan panduan kebijakan penggunaan antimikroba, sehingga pada bulan Mei dibentuk Tim Pengendalian Resistensi Antimikroba (PPRA) RSUD Arifin Ahmad untuk mengevaluasi penggunaan antibiotik. Tujuan penelitian ini adalah menganalisis rasionalitas penggunaan antibiotik di RSUD Arifin Ahmad setelah implementasi Kebijakan panduan penggunaan antibiotik (PPAB), mengetahui persentase penggunaan antibiotik dengan kriteri Gyssens, pemeriksaan kultur dan sensitivitas.

\section{METODE}

Penelitian ini dilaksanakan di Bangsal Kenanga yang merupakan ruang rawat inap medikal RSUD Arifin Ahmad (RSUD AA) Pekanbaru pada periode Maret-Agustus 2016. Jenis penelitian ini merupakan penelitian analitik dengan pengambilan data secara retrospektif untuk kelompok pre implementasi, dan prospektif untuk pasca implementasi. Metoda pengambilan sampel dengan total sampling. Kriteria inklusi pada penelitian ini meliputi pasien yang berusia $>18$ tahun, mendapat antibiotik (terapi empiris, definitif, maupun profilaksis), dan catatan medis yang lengkap.

Langkah awal yang dilakukan adalah penyusunan Pedoman Pemberian Antibiotik (PPAB) dan selanjutnya disetujui oleh Kelompok Staf Fungsional Penyakit Dalam RSUD Arifin Achmad, sosialisasi PPAB dan penguatan komitmen dari manajemen rumah sakit dan Komite PPRA.

Rasionalitas penggunaan antibiotik menggunakan alur penilaian sesuai metode Gyssens (9). Setiap antibiotik yang diresepkan akan dinilai mengikuti sebuah alur yang kemudian diklasifikasikan ke dalam kategori yang meliputi: kategori 0 (penggunaan antibiotik tepat/bijak), kategori I (penggunaan antibiotik tidak tepat waktu), kategori IIA (penggunaan antibiotik tidak tepat dosis), kategori IIB (penggunaan antibiotik tidak tepat interval pemberian), kategori IIC (penggunaan antibiotik tidak tepat cara/rute pemberian), kategori IIIA (penggunaan antibiotik terlalu lama), kategori IIIB (penggunaan antibiotik terlalu singkat), kategori IVA (ada antibiotik lain yang lebih efektif), kategori IVB (ada antibiotik lain yang kurang toksik/lebih aman), kategori IVC (ada antibiotik lain yang lebih murah), kategori IVD (ada antibiotik lain yang spektrumnya lebih sempit), kategori $\mathrm{V}$ (tidak ada indikasi penggunaan antibiotik), kategori VI (data rekam medik tidak lengkap dan tidak dapat dievaluasi).

Peresepan antibiotik dinilai oleh tim pengkaji dengan menggunakan bagan alur tersebut. Tim pengkaji minimal berjumlah dua orang, dan merupakan anggota dari Tim PPRA, dan sebagiannya adalah peneliti. Beberapa pertanyaan panduan harus ditanyakan oleh tim pengkaji secara lengkap kepada dokter untuk evaluasi secara menyeluruh agar tidak terdapat parameter penting yang terlewat. Evaluasi berlangsung serial dari pertanyaan pertama sampai pertanyaan terakhir. Peresepan dapat tidak tepat dalam beberapa kategori secara bersamaan.

Analisis statistik uji Chi Square (SPSS versi 15) digunakan untuk menilai perbedaan rasionalitas sebelum dan pascaimplementasi kebijakan antibiotik di RSUD Arifin Ahmad, dengan nilai $p<0,05$ dianggap bermakna.

\section{HASIL}

Selama periode penelitian, didapatkan data 77 pada kelompok pre-implementasi dan 139 pasien pascaimplementasi kebijakan penggunaan antimikroba yang 
mendapatkan antibiotik di Bangsal Kenanga. Untuk periode pasca implementasi didapatkan 139 dari 410 pasien mendapatkan antibiotika dari bulan Juni hingga Agustus 2016 (33,9\%). Pemberian lebih dari 1 antibiotik pada seorang pasien dimungkinkan terjadi karena alasan medis sehingga didapatkan jumlah pemberian antibiotik sebanyak 92 pada kelompok sebelum dan 160 pada kelompok sesudah implementasi kebijakan penggunaan antimikroba. Pemberian antibiotik ini dapat dilakukan dengan pertimbangan empiris maupun definitif sesuai hasil kultur.

\section{Penilaian Penggunaan Antibiotik dengan Alur Gyssens}

Hasil kajian secara bertingkat oleh tim pengkaji terhadap 252 penggunaan antibiotik menujukkan bahwa terdapat perubahan pola kualitas penggunaan antibiotik berdasarkan alur dari Gyssens pada semua kategori mulai dari Gyssens 0 hingga Gyssens V (tabel 1).

Dari data tabel 1 terlihat adanya progresifitas persentase pemberian antibiotik secara rasional (kategori 0) meningkat dari 33,7\% menjadi 48,8\% (peningkatan sebesar 15,1\%) dan pemberian antibiotik tanpa ada indikasi (kategori V) menurun dari 27,2\% menjadi 16,3\% (penurunan sebesar $10,9 \%)$. Masih didapatkan penggunaan antibiotik yang tidak rasional (Gyssens I, II, III, IV).

Tabel 1. Penilaian kategori Gyssens untuk menilai rasionalitas antibiotik

\begin{tabular}{lcccc}
\hline $\begin{array}{l}\text { Katagori } \\
\text { Gyssens }\end{array}$ & $\begin{array}{c}\text { Kelompok Pre- } \\
\text { implementasi }\end{array}$ & $\begin{array}{c}\text { Persentase } \\
\text { (\%) }\end{array}$ & $\begin{array}{c}\text { Kelompok } \\
\text { pasca- } \\
\text { Implementasi }\end{array}$ & $\begin{array}{c}\text { Persentase } \\
\text { (\%) }\end{array}$ \\
\hline $\mathbf{0}$ & 31 & 33,7 & 78 & 48,8 \\
IIA & 1 & 1,1 & 1 & 0,6 \\
IVA & 33 & 35,9 & 52 & 32,5 \\
IVC & 2 & 2,2 & 2 & 1,3 \\
IVD & 0 & 0,0 & 0 & 0,0 \\
V & 25 & 27,2 & 26 & 16,3 \\
VI & 0 & 0,0 & 1 & 0,0 \\
TOTAL & 92 & 100 & 160 & 100 \\
\hline
\end{tabular}

Analisis Rasionalitas Penggunaan Antibiotik Setelah Implementasi Panduan Penggunaan Antibiotik

Hasil uji perbandingan rasionalitas penggunaan antibiotik setelah implementasi panduan penggunaan antibiotik (tabel 2) menunjukkan perubahan yang bermakna, yaitu terjadi peningkatan persentase penggunaan antibiotik secara rasional $(p=0,020)$, dan penurunan penggunan antibiotik yang tanpa indikasi $(p=0,038)$.

Tabel 2. Uji analisis statistik

\begin{tabular}{clcccc}
\hline Kategori & $\begin{array}{c}\text { Kelompok Pre- } \\
\text { implementasi }\end{array}$ & $\begin{array}{c}\text { Kelompok } \\
\text { Pasca- } \\
\text { implementasi }\end{array}$ & Total & $\begin{array}{c}\text { p } \\
\text { (Chi } \\
\text { square) }\end{array}$ \\
\hline \multirow{3}{*}{ Gyssens 0 } & Ya & 31 & 78 & 92 & \\
& Tidak & 61 & 82 & 160 & 0,020 \\
& Total & 92 & 160 & 252 & \\
& Ya & 25 & 26 & 92 & \\
Gyssens V V & Tidak & 67 & 134 & 160 & 0,038 \\
& Total & 92 & 160 & 252 & \\
\hline
\end{tabular}

\section{Pemeriksaan Kultur Secara Awal}

Sosialisasi setelah implementasi pedoman pemakaian antibiotik, kesadaran untuk pemeriksaan kultur meningkat. Kesadaran untuk melakukan atau mengambil spesimen kultur sangat meningkat pada kelompok pascaimplementasi (Tabel 3). Ini merupakan hasil yang positif karena mengindikasikan klinisi sudah mulai tergugah untuk melakukan pemeriksaan kultur sebelum memberikan terapi empiris.

Tabel 3. Persentase terapi empiris dan definitif

\begin{tabular}{lccc}
\hline & $\begin{array}{c}\text { Tidak dilakukan } \\
\text { kultur }\end{array}$ & $\begin{array}{c}\text { Dilakukan } \\
\text { Kultur }\end{array}$ & Jumlah \\
\hline Pre-implementasi program & $79(85,8 \%)$ & $13(14,2 \%)$ & 92 \\
Pasca-implementasi program & $45(28,1 \%)$ & $115(71,9 \%)$ & 160 \\
\hline
\end{tabular}

\section{DISKUSI}

Sudah diketahui secara luas bahwa penggunaan antibiotik yang tidak rasional akan memicu terjadinya resistensi antibiotik. Hal ini menimbulkan suatu infeksi mikroorganisme tidak dapat lagi diobati dengan antibiotik biasa, yang berakibat perlunya antibiotik jenis baru dengan spektrum lebih luas. Penggunaan antibiotik jenis yang lebih baru akan juga meningkatkan biaya perawatan disamping morbiditas dan mortalitas (13). Untuk mendorong penggunaan antibiotik yang rasional, maka diperlukan panduan penggunaan antibiotik empiris secara berkala dengan mempertimbangkan pola kuman dan resistensinya. Data pola kuman dan resistensi sudah tersedia di RSUD Arifin Ahmad, namun data tersebut belum dipakai sebagai dasar terapi pada umumnya. Pada periode sebelumnya, jenis antibiotik yang tersedia sering tidak sesuai dengan pola kuman dan sensitivitas pada tahun sebelumnya.

Untuk mendukung program nasional pengendalian resistensi antimikroba, maka dibentuk Komite Program Pengendalian Resistensi Antimikroba (PPRA) yang dikenal juga dengan istilah antimicrobial stewardship. Langkah awal adalah pembuatan buku pedoman/panduan penggunaan antibiotik empiris yang disepakati oleh klinisi di Bagian Penyakit Dalam untuk diimplementasikan dalam penatalaksanaan pasien di Bangsal Kenanga. Di samping itu, program ini mendapatkan dukungan dari manajemen dalam bentuk penyediaan antibiotik-antibiotik yang sudah disepakati sebagai alternatif utama terapi empiris.

Survei pendahuluan menunjukkan bahwa persentase peresepan antibiotik di bangsal Kenanga ternyata masih tinggi yaitu mencapai 33,9\%. Angka ini bahkan lebih tinggi dari penelitian Irene Yuniar dkk. di ICU RSCM yang mencapai 19,3\% (14). Tingginya peresepan antibiotik ini perlu ditindaklanjuti dengan menganalisis faktor-faktor penyebabnya dan alasan klinisnya.

Rasionalitas penggunaan antibiotik dikaji dengan alur dari Gyssens. Didapatkan peningkatan persentase kriteria Gyssens 0 sebesar 15,1\% pasca implementasi pedoman penggunaan antibiotik, dimana angka total mencapai sebesar $48,8 \%$ (dibandingkan sebelumnya hanya 33,7\%). Hasil penelitian ini hampir sama dengan penelitian oleh Yuniar I tahun 2013, di populasi ICU yaitu penggunaan antibiotik rasional mencapai 53\% (14). Peningkatan 
persentase kriteria dari Gyssens 0 antara lain disebabkan karena kepatuhan klinisi akan pedoman terapi antibiotik secara empiris mulai muncul.

Presentase penggunaan antibiotik tanpa indikasi sebelum implementasi pedoman penggunaan antibiotik cukup tinggi yaitu mencapai $27,2 \%$. Angka ini lebih rendah dibandingkan, penelitian oleh Hadi U dkk., di Surabaya yang mendapatkan bahwa $32 \%$ peresepan antibiotik indikasinya tidak jelas (15), dan penelitian oleh Sri A, 2014 yang menunjukkan hasil yang mirip yaitu terdapat $35 \%$ peresepan antibiotik tanpa indikasi pada pasien yang dirawat di Bedah Digestif di Bandung (16). Hasil penelitian dari studi Antimicrobial Resistence in Indonesia (AMRIN study) tahun 2000-2004 juga menunjukan hasil yang lebih tinggi yaitu terapi antibiotik diberikan tanpa indikasi di RSUP Dr Kariadi Semarang sebanyak 20-53\% dan antibiotik profilaksis tanpa indikasi sebanyak 43-81\% (17). Setelah implementasi pedoman penggunaan antibiotik, didapatkan penurunan pemberian antibiotik tanpa indikasi sebesar 10,9\%. Penurunan ini diyakini dapat menurunkan kemungkinan terjadinya resistensi antibiotik di masa yang akan datang. Fenomena masih dijumpainya pemberian antibiotik secara tidak rasional dan tanpa indikasi masih menyisakan pekerjaan rumah yaitu sosialisasi secara terus menerus mengenai program pengendalian resistensi antibiotik (PPRA) harus didengungkan setiap saat dan membutuhkan komitmen dari semua elemen. Negara KS dalam artikelnya menyatakan bahwa dalam implementasi kebijakan penggunaan antibiotik di rumah sakit, peranan sumber daya manusia dalam hal ini dokter dan tenaga medis lainnya sangat besar (8). Dokter yang menentukan dan juga memberikan antibiotik sesuai dengan kasus, sedangkan peran paramedis mengingatkan dokter yang merawat pasien untuk mengikuti PPAB, seperti lama pemberian antibiotik, peralihan antibiotik dari intravena ke oral, pengisian formulir pemberian antibiotik dengan lengkap, serta pengisian rekam medik termasuk alergi, lama dan frekuensi pemberian antibiotik, cara pemberian, dan efek samping yang terjadi (8).

Hal positif lain yang ditemukan pada PPRA ini adalah

\section{DAFTAR PUSTAKA}

1. Centers for Disease Control and Prevention. Antibiotic Resistance Threats in the United States, 2013. (Online) 2013. https://www.cdc.gov/ drugresistance/pdf/ar-threats-2013-508.pdf. [diakses tanggal 10 Oktober 2016].

2. Departemen Kesehatan Republik Indonesia. Peraturan Menteri Kesehatan Nomor: 2406/MENKES/PER/XII/2011 tentang Pedoman Umum Penggunaan Antibiotik. Jakarta: Departemen Kesehatan RI; 2011.

3. Ventola CL. The Antibiotic Resistance Crisis: Part 1: Causes and Threats. Pharmacy and Therapeutics. 2015; 40(4): 277-283.

4. Planta MB. The Role of Poverty in Antimicrobial Resistance. Journal of the American Board of Family Medicine. 2007; 20(6): 533-539.

5. Bao L, Peng R, Wang Y, et al. Significant Reduction of Antibiotic Consumption and Patients' Costs after an meningkatnya kesadaran klinisi untuk melakukan pemeriksaan kultur dan sensitivitas kuman. Sebanyak $79,1 \%$ spesimen kultur dilakukan pemeriksaan sebelum diberikan antibiotik. Data ini sangat penting untuk mengidentifikasi jenis jenis kuman patogen yang ada sekaligus menentukan antibiotik definitif yang paling tepat secara in vitro. Pola kuman yang didapat ini sangat bermanfaat untuk pembaharuan pedoman penggunaan antibiotik empiris di tahun berikutnya. Mikrobiologi klinik sebagai salah satu pilar dari PPRA, laboratorium ini yang melakukan pemeriksaan kultur dan tes sensitivitas pada kasus-kasus infeksi yang berat dan merekomendasikan penggantian antibiotik pada kasus-kasus tertentu (8). Kecepatan keluarnya hasil kultur ini dalam menentukan hasil sangat menentukan lama tidaknya masa rawat. Implementasi Pedoman Penggunaan antibiotik di Bangsal Kenanga sebagai program awal dari PPRA memberikan gambaran bahwa dengan komitmen dari berbagai pilar PPRA yaitu Klinisi, mikrobiologi klinik, farmasi klinik, keperawatan, Komite Farmakoterapi, dan Komite Pencegahan dan Pengendalian Infeksi. sangat diperlukan untuk mencapai keberhasilan program. Melihat bahwa terdapat peningkatan persentase rasionalitas penggunaan antibiotik dengan pemberlakuan PPAB maka perlu untuk mengembangkan PPAB di divisi lain yang penggunaan antibiotiknya tinggi termasuk antibiotik profilaksis (2).

Selain di rumah sakit, program pengendalian resistensi antimiroba dapat juga dilaksanakan di masyarakat, sehingga masyarakat mengerti akan pentingnya menggunakan antibiotik dengan bijak. Edukasi kepada masyarakat dapat dilakukan melalui kelompok-kelompok kecil dengan kegiatan berupa penyuluhan, modul dan diskusi kelompok kecil (17).

\section{UCAPAN TERIMA KASIH}

Terimakasih dan penghargaan kami sampaikan kepada Pimpinan FK UR karena telah memberikan dana hibah penelitian fakultas untuk penelitian ini , manajemen RSUD Arifin Ahmad, Klinisi KSM Penyakit Dalam, Mikrobiologi Klinik, Komite Farmasi dan terapi yang telah bekerja sama dalam menjalankan program PPRA.

Action Plan in China, 2010-2014. PloS ONE. 2015; 10(3): 1-13.

6. World Health Organization. Containing Antimicrobial Resistance-WHO Policy Perspectives of Medicine. (Online) 2005. http://apps.who.int/medicinedocs /pdf/s7920e/s7920e.pdf. [diakses tanggal 10 Oktober 2016].

7. Hanberger H, Skoog G, Ternhag A, and Giske CG. Antibiotic Consumption and Antibiotic Stewardship in Swedish Hospitals. Upsala Journal of Medical Sciences. 2014; 119(2): 154-161.

8. Negara KS. Analisis Implementasi Kebijakan Penggunaan Antibiotika Rasional Untuk Mencegah Resistensi Antibiotika di RSUP Sanglah Denpasar: Studi Kasus Infeksi Methicillin Resistant Staphylococcus aureus. Jurnal Administrasi Rumah Sakit Indonesia. 2014; 1(1): 42-50.

9. Luciana, Andrajati R, Rianti A, and Khan AH. Rational Antimicrobial Use in an Intensive Care Unit in Jakarta, Indonesia: A Hospital-Based, Cross-Sectional Study. 
Tropical Journal of Pharmaceutical Research. 2015; 14(4): 707-714.

10. Trisnadewi IGA, Suharjono, Hardiono, and Widodo ADW. Analysis of Antibiotic Usage in Patients with Bacteremia in the ICU of dr. Soetomo Hospital Surabaya. Folia Medica Indonesiana. 2014; 50(4): 254-261.

11. Morgan DJ, Okeke IN, Laxminaraya R, Perencevich $E L$, and Weisenberg S. Non-Prescription Antimicrobial Use Worldwide: A Systematic Review. The Lancet. Infectious Diseases. 2011:11(9): 692-701.

12. Fletcher S. Understanding the Contribution of Environmental Factors in the Spread of Antimicrobial Resistance. Environmental Health and Preventive Medicine. 2015; 20(4): 243-252.

13. Spellberg B and Gilbert DN. The Future of Antibiotics and Resistance: A Tribute to a Career of Leadership by John Bartlett. Clinical Infectious Diseases. 2014; 59(suppl 2): S71-S75.

14. Yuniar I, Karyanti MR, Tambunan T, and Rizkyani NA. Evaluasi Penggunaan Antibiotika dengan Kartu Monitoring Antibiotika Gyssens. Sari Pediatri. 2013; 14(6): 384-390.

15. Hadi U, Duerink DO, Lestari ES, et al. Audit of Antibiotic Prescribing in Two Governmental Teaching Hospitals in Indonesia. Clinical Microbiology and Infection. 2008; 14(7): 698-707.

16. Sumiwi SA. Kualitas Penggunaan Antibiotik pada Pasien Bedah Digestif di Salah Satu Rumah Sakit di Bandung. Jurnal Farmasi Klinik Indonesia. 2014; 3(4): 135-140.

17. Mahardika AB, Suryawati S, and Aji R. Intervensi CBIA untuk Meningkatkan Pengetahuan, Sikap dan Perilaku Penggunaan Antibiotik yang Rasional pada Anggota Bina Keluarga Balita. Jurnal Kedokteran Brawijaya. 2016; 29(2): 165-169. 